\title{
Going Online with Arboricultural Education
}

\author{
Mark Johnston and Andrew Hirons
}

\begin{abstract}
E-learning is the delivery of learning, training, or education programs by electronic means. Over the past two decades this has become an increasingly popular way of delivering higher education courses, as this form of delivery provides significant benefits to students and the academic institution. Myerscough College has been a pioneer in developing a fully online degree level course in arboriculture not only in Britain, where the college is based, but also internationally with students now studying online in many different countries. This paper describes how the e-learning degree programs were developed, including the various challenges the programs faced and the interventions that were made to overcome them. It also presents a model for the development of e-learning vocational programs for arboriculture and related industries that other institutions may wish to use or adapt. The paper concludes with an indication of likely future developments in e-learning in arboriculture.

Key Words. Career Development; Continuous Professional Development; E-learning; Higher Education; Vocational Courses.
\end{abstract}

\section{ARBORICULTURAL EDUCATION AND DISTANCE LEARNING IN BRITAIN}

Non-compulsory education in Britain is divided into two main strands: further education and higher education. Further education is focused on education up to, but not including, university level courses. Higher education includes undergraduate and post-graduate qualifications.

The initial development of arboricultural education in Britain began in the late 1950s with the establishment of the first formal qualifications in the subject (Bridgeman 1976). These were offered by the Royal Forestry Society of England, Wales, and Northern Ireland, but at the time there were no full-time or part-time educational courses to prepare students for the examinations. In the late 1960s, specialist arboricultural courses were first established at further education level, primarily through Merrist Wood College in Surrey (Bridgeman 2009). However, for many years arboricultural education in Britain continued to be less developed than that of related professions, such as horticulture, forestry, and landscape architecture (Johnston 2001a). It was not until 1992 that the first higher education-level course became available when Myerscough College in Lancashire began its Higher National Diploma in Arboriculture (Johnston 2001b). Then, Myerscough College developed the first degree-level arboricultural course when its BSc (Hons) in arboriculture started in 1998.

During the late 1990s and early 2000s, the demand for arboricultural education grew rapidly, particularly at the higher education level. This was fueled by an increasing drive within the industry to place arboricultural professionals on a similar level to established graduate professions such as forestry, landscape architecture, and planning. The technical aspects of arboriculture and urban forest management had advanced dramatically in the past two decades and educational courses in these subjects needed to reflect this growth.
At the beginning of the 2000s, Myerscough College was the only educational establishment in Britain offering arboricultural courses at higher education or degree level. However, it was becoming apparent to Myerscough's staff that full-time or even part-time courses were not a convenient option for many potential students. The need to physically attend college was a major disincentive, even for those considering part-time courses. For many potential students, the travel distance to the college, together with employer reluctance to agree to day-release to attend classes, was a major obstacle.

There had been a number of early efforts to promote distance learning in arboriculture. The Horticultural Correspondence College had been offering arboricultural courses at further education level by distance learning since the mid-1980s (Menhinick 2010, pers. comm.). From 1997, an arboricultural education and training provider called Treelife began offering more advanced distance learning material at HE level, but these were also correspondence materials (Dowson 2010, pers. comm.). However, over the past two decades, the correspondence course as a method of delivering distance learning has been largely replaced with the development of e-learning, the delivery of learning, training, or education programs by electronic means (Harasim et al. 1995; Rudestam and SchoenholtzRead 2010). E-learning involves the provision of these learning, training, or education materials via the internet, network, standalone computer, mobile phone, or other electronic device. With the expanding role of the internet in society and the emerging field of e-learning it became Myerscough's vision to provide an online, degree-granting opportunity in arboricultural education.

\section{THE BENEFITS OF E-LEARNING}

Developing an e-learning portfolio offers substantial benefits for potential learners and the academic institution. Increasing 
access to study regardless of location is clearly of value to students who are committed to their current place of residence. The flexibility of access facilitates study in conjunction with employment or other commitments (Cole 2000). Course literature can be updated and distributed very efficiently by tutors (Rosenberg 2001). This not only helps to facilitate the delivery of contemporary and relevant academic courses, but also helps organizations deliver continuous professional development to their employees or members. Sitzmann et al. (2006) indicate that web-based instruction can be at least as effective as classroom instruction. Some authors actually indicate that the quality of online learning will exceed that of classroom-based teaching in the future (Kim and Bonk 2006). The development of an e-learning portfolio at an academic institution ensures a competitive advantage, removes geographical limitations on student intake, and acts to raise the reputation of the institution on an international scale.

Additional potential benefits of e-learning can include improved performance from higher education students in contrast to those in face-to-face courses; higher standards of teaching, as teachers of the highest caliber can share their knowledge across borders to everyone who is interested and at minimum cost; and the ability to improve students' essential skills in the use of information and communications technologies by embedding the use of this within the curriculum (Anderson and Elloumi 2004). Further discussion on the value of e-learning can be found in established texts such as Jarvis (2004), McPhenson and Nunes (2004), Beetham and Sharp (2007), and Rudestam and Schoenholtz-Read (2010).

\section{THE DEVELOPMENT OF GRADUATE E-LEARNING IN ARBORICULTURE}

Myerscough College's degree courses are validated by the University of Central Lancashire, which is based in the nearby city of Preston. In order to offer an online degree course in arboriculture, Myerscough had to provide sufficient evidence to convince the University of Central Lancashire that there was a demand for this. To this end, an "expression of interest" form was placed on the college website. Anyone who thought they might consider studying online for such a degree at some point in the future was asked to complete this form. Within six months, 153 people had completed the form, a response viewed by curriculum managers as very encouraging.

Further evidence to support the need for the course was provided by the college's Technical Advisory Board for arboricultural courses. The Technical Advisory Board includes representatives from relevant professional bodies, trade associations, and major industry employers. There was overwhelming support from the members of the Board for the proposal to develop an online degree in arboriculture. With evidence of the need for the course from both the expression of interest form on the college website and from the Technical Advisory Board, the development of such a course was included in the college's main Strategic Plan 2005-2010 (Myerscough College 2005) as well as the college's E-Learning and ILT Strategies (Myerscough College 2006a; Myerscough College 2006b).

To support the academic staff in the development of online learning resources, Myerscough College established the Learning Development Unit to provide additional technical expertise. Academic staff, supported by the Learning Development Unit, then began the significant task of transferring existing lecture notes and materials into a format that could be delivered through a virtual learning environment. This work initially focused on the online Foundation Degree in Arboriculture (FdSc) (which had replaced the previous Higher National Diploma) and was a threeyear part-time course. This was first offered in 2003, and the positive response to this educational opportunity translated into a substantial number of applicants. It was apparent that the recruitment needs of the industry were evolving and local authorities and consultancy companies were increasingly requiring degree-level personnel to make management decisions on trees. However, the college decided to limit the number of students on this course to approximately 20 each year while it was in its formative stages.

While it was clear from the Technical Advisory Board meetings and other industry liaison activities that there were significant opportunities in delivering online learning in arboriculture. There were also major challenges that needed to be met. These challenges included: staff training, to familiarize them with the virtual learning environment; designing sessions to achieve learning outcomes that would normally be instructed face-to-face and with campus resources; communicating with online learners; and student perspective (self-discipline, isolation, asynchronous feedback to questions, lack of learner community, and lack of diversity in sessions).

\section{CHALLENGES TO ONLINE DELIVERY}

Two criteria, achievement and success, are used to evaluate the overall performance of academic courses. Achievement reflects the percentage of students who were enrolled for the duration of the course and passed the qualification. Success considers the percentage of students who passed the qualification as a function of the number of students enrolled in the first year. Therefore, any disparity between achievement and success is related to student retention on the course.

Success rates were suppressed in the 2005-2006 and 20062007 academic years as a result of poor student retention (Table 1; Figure 1). This presented a significant challenge to the FdSc course and it was critical that such low levels of retention and, therefore, success did not persist. Analysis of student feedback, internal quality assurance processes, and other empirical evidence gave the academic team a number of specific areas to focus on.

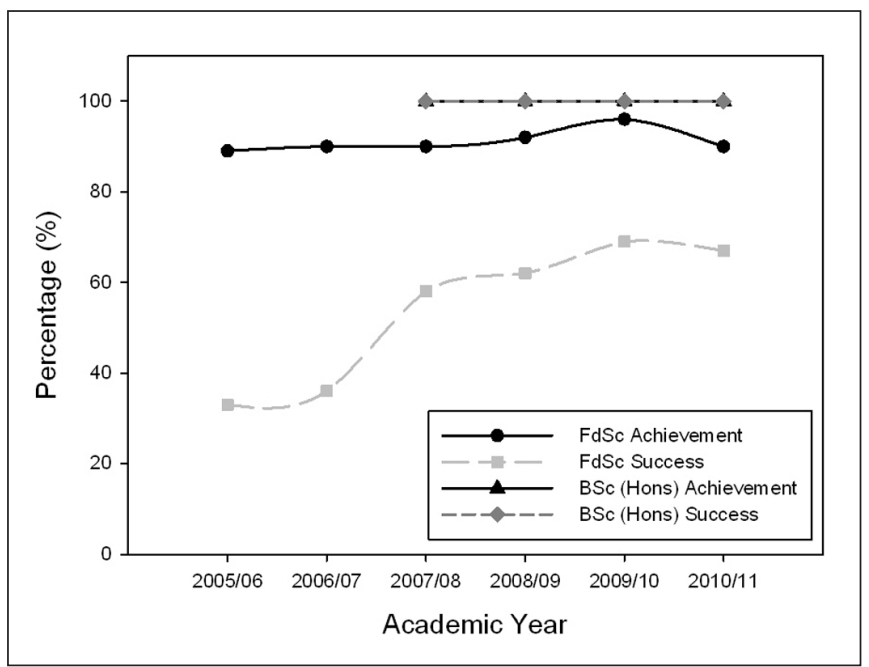

Figure 1. Raising achievement and success in online, higher education arboriculture courses. 
The importance of managing student expectations became apparent as the challenge of completing a higher education course in tandem with full-time employment and family life was significant. Advice at the recruitment stage was reviewed and refined in response to this feedback. Emphasis was given to the level of commitment required for the course at point of enquiry.

The appeal of the course to practitioners wishing to develop and enhance their knowledge frequently led to challenges associated with technology literacy, as students moved, not simply from the workplace to the learning environment, but also to a format of learning that was not immediately intuitive to them. In particular, asynchronous interaction with tutors and student colleagues was in contrast to the experience of a face-to-face learning environment and resulted in some students feeling academically isolated. In other cases, a lack of confidence in the use of information technology and electronic resources further exacerbated retention issues.

The industry consultation exercises gave staff confidence that the curriculum was well-designed and met the needs of the arboricultural industry. However, the diversity of course delivery achieved in face-to-face teaching proved difficult to emulate in a computer-mediated environment. For example, group interaction and discussion, practical exercises, and formative assessment all represent challenges in an online environment. Therefore, while the increased accessibility of elearning may enhance provision, the difference in pedagogical and andragogical approaches may limit some individuals with specific learning styles. In the early stage of course development, the principle mechanism for delivering subject material was through session booklets (.pdf documents detailing a module-specific topic). These were supported by various interactive activities that supported and assessed learning, such as drag-and-drop exercises, online microscopes (a zoom facility for viewing digital micrographs), and self-assessment tests. Reflective and theorist learners (Honey and Mumford 1992) were favored by this strategy, so mechanisms to support a broader range of learning styles needed to be explored.

\section{INTERVENTIONS - IMPROVING SUCCESS}

Three key areas were identified in order to enhance retention statistics and elevate the e-learning experience. These areas included: learner engagement, learning resources, and learner support (Figure 2). An action research framework (Cohen and
Manion 1994) was adopted where possible to give academic staff and curriculum managers robust information to assess new approaches. In these cases, interventions were planned to enhance the learning experience and evaluate, using electronic surveys, evidence from online discussion forums, e-mail correspondence, and oral feedback. This provided qualitative and quantitative data from a number of sources, which was then used to inform course evaluation and externally administrated reviews such as the Integrated Quality and Enhancement Review (a UK Higher Education quality assurance system).

Emerging technologies, including online conferencing software such as Macromedia Breeze ${ }^{\mathrm{TM}}$ (now called Adobe ${ }^{\circledR}$ Connect $\left.{ }^{\mathrm{TM}}\right)$, were tried with great success as a mechanism to provide remote learners with synchronous and engaging learning events (Hirons 2007); this built on previous work in the field by Harker et al. (2005) and Khiewnavawongasa et al. (2006). In recognition of this, the use of screen-casts to deliver core materials and as aids to understanding important software packages used during the course was expanded. Slater (2008) found that the use of audio engaged a wider range of learning styles, supported students with learning difficulties and disabilities (e.g., dyslexia) and assisted with the pronunciation of technical terms. This was particularly valuable for students who spoke English as a second language. Other approaches to increase learner engagement included the use of short video clips, further development of existing interactive self-assessment tasks, and an increased emphasis on the use of discussion forums embedded within the virtual learning environment. All of these interventions required the close collaboration of academic staff, the technical expertise of the Learning Development Unit, and focused continuous professional development.

A program of peer-review and online lesson observations was instigated by the quality assurance team at Myerscough College. The impact of this was to start a formal cycle of sharing best practices and further enhance collegiate support. Where modules, for example, are shown to appeal to a narrow range of learning styles or have limited learner engagement, an action plan was created to help progress the module and bring it up to a higher standard. Greater personal learner support was facilitated by the increased provision of time to the staff that had direct responsibility for the management of the online courses.

The combined impact of these interventions was that students were retained and success rates were greatly enhanced. The FdSc acts as a significant feeder course to the online BSc (Hons) course, and as a result the majority of students are

Table 1. Key completion data from e-learning courses.

\begin{tabular}{|c|c|c|c|c|c|c|c|}
\hline & & \multicolumn{6}{|c|}{ Completion year } \\
\hline & & $2005-06$ & $2006-07$ & $2007-08$ & $2008-09$ & $2009-10$ & $2010-11$ \\
\hline $\begin{array}{l}\text { Foundation degree in } \\
\text { arboriculture (FdSc) }\end{array}$ & $\begin{array}{l}\text { Recruitment }^{\mathrm{z}} \\
\text { Retention }^{\mathrm{y}} \\
\text { Achievement }^{\mathrm{x}} \\
\text { Success }^{\mathrm{w}}\end{array}$ & $\begin{array}{l}49 \\
37 \% \\
89 \% \\
33 \%\end{array}$ & $\begin{array}{l}25 \\
40 \% \\
90 \% \\
36 \%\end{array}$ & $\begin{array}{l}33 \\
64 \% \\
90 \% \\
58 \%\end{array}$ & $\begin{array}{l}37 \\
68 \% \\
92 \% \\
62 \%\end{array}$ & $\begin{array}{l}32 \\
72 \% \\
96 \% \\
69 \%\end{array}$ & $\begin{array}{l}24 \\
75 \% \\
90 \% \\
67 \%\end{array}$ \\
\hline $\begin{array}{l}\text { BSc (Hons) } \\
\text { in arboriculture } \\
\text { (direct entry) }\end{array}$ & $\begin{array}{l}\text { Recruitment } \\
\text { Retention } \\
\text { Achievement } \\
\text { Success }\end{array}$ & $\begin{array}{l}0 \\
\text { N/A } \\
\text { N/A } \\
\text { N/A }\end{array}$ & $\begin{array}{l}0 \\
\text { N/A } \\
\text { N/A } \\
\text { N/A }\end{array}$ & $\begin{array}{l}4 \\
100 \% \\
100 \% \\
100 \%\end{array}$ & $\begin{array}{l}8 \\
100 \% \\
100 \% \\
100 \%\end{array}$ & $\begin{array}{l}14 \\
100 \% \\
100 \% \\
100 \%\end{array}$ & $\begin{array}{l}10 \\
100 \% \\
100 \% \\
100 \%\end{array}$ \\
\hline
\end{tabular}

${ }^{\mathrm{z}}$ Number of students enrolling on the course.

${ }^{y}$ Percentage of students that completed the course.

${ }^{x}$ Percentage of students who pass the qualification.

${ }^{\text {w }}$ Percentage of students who enrolled and went on to gain the qualification. 


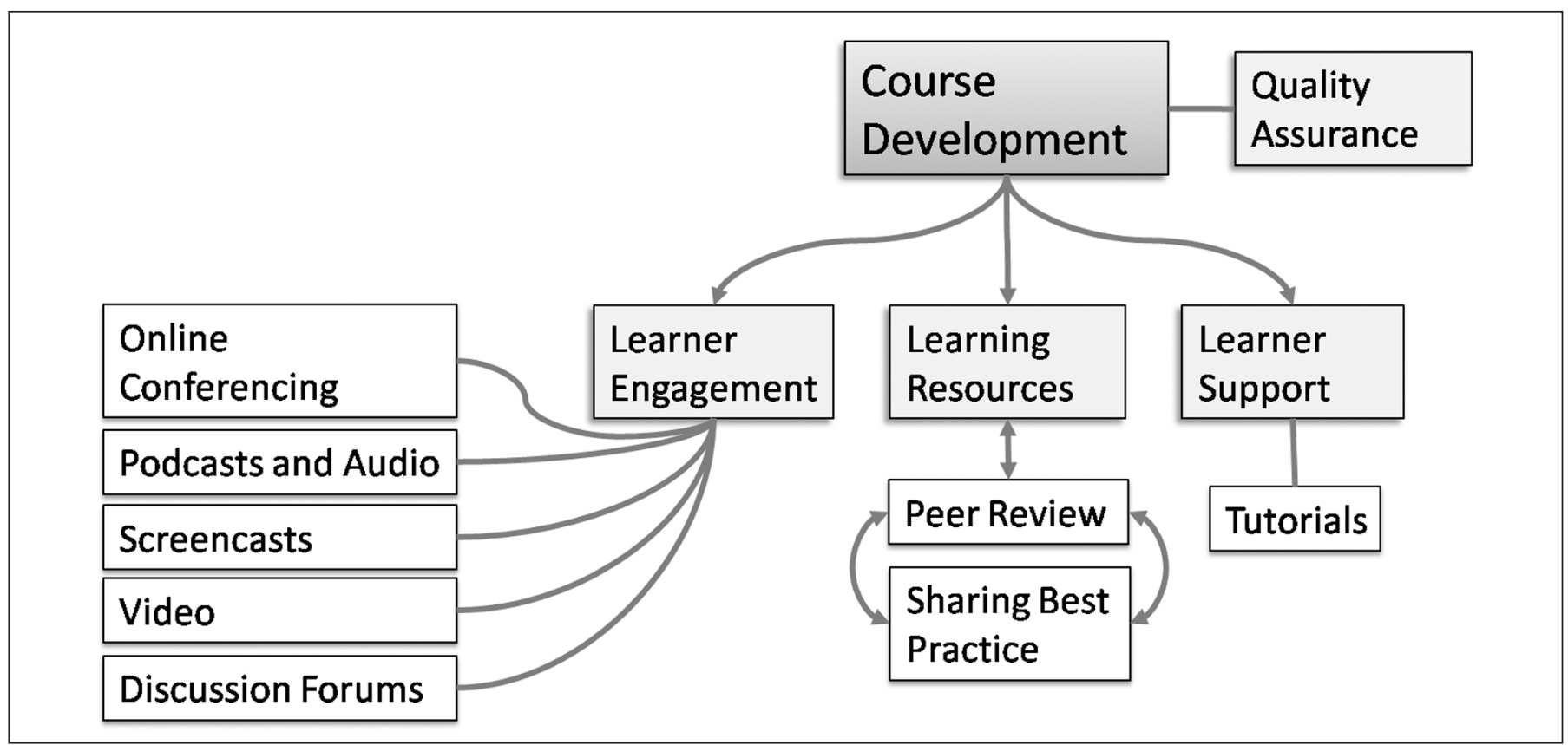

Figure 2. Important interventions to enhance course success.

well-accustomed to online study approaches. The formative period early in the $\mathrm{FdSc}$ and subsequent interventions also fed directly into the delivery of the higher level course. Consequently, achievement and success for the BSc (Hons) online degree have been maintained at 100\% (Table 1; Figure 1).

\section{MODEL FOR E-LEARNING DEVELOPMENT}

The experience at Myerscough College has enabled the construction of a simple four phase model for the development of online courses in arboriculture and related vocational subjects (Figure 3 ). The initial phase, Conceptualization, was provided from academic staff with a vision pursuant of the emerging needs of the arboricultural industry. A critical driver in moving the online course development forward was its inclusion in the strategic plan, which ensured it gained support at an institutional governance level. As part of this first stage, staff had to robustly demonstrate the market potential for these online courses to senior management.

Having secured strategic support, the next phase of the Construction of resources took priority. The Learning Development Unit was established to provide technical support and the infrastructure needed for the delivery of courses online. This included adopting a virtual learning environment, initially using the Blackboard Academic Suite ${ }^{\mathrm{TM}}$ platform, and later Moodle. Specialist skills and technical expertise were required for the development of e-learning resources. Core course materials were developed by the existing academic staff with the integration of other resources available to higher education students at the college, such as academic library databases (e.g., Athens or Shibboleth). Without this specialist technical support from the Learning Development Unit, staff would not have been able to develop learning resources to the same professional standard.

The preliminary stage of Realization involved extensive consultation with arboricultural professionals to ensure that the final course was congruent with industry requirements. In general, learning is designed to be self-regulated, goal-orientated, and cumulative. Assessed work is either designed to develop foundational skills, such as scientific writing, or to represent authentic vocational tasks. This broadly follows the constructivist model of learning developed by theorists like Piaget (1970). The anticipated dominance of adult learners on the online degree programme also brought focus to the andragogical principles developed by Knowles et al. (2005). This required that the reasons for learning particular content are very clear, personal experience can be integrated into learning, and that learners are involved with the planning and evaluation of assessment (where possible). It was clear that assessment needed parity with the equivalent full-time students and so was modified only in cases where the physical resources did not allow some activities to take place. In all cases, the learning outcomes being assessed remained constant. Course delivery needed the collaboration of academic subject specialists and technical staff from the Learning Development Unit. Inevitably, staff required continuous professional development training to ensure fluency in course delivery.

The final phase is one of Evolution, in which the course is continuously developed as a result of internal quality assurance processes, adoption of new technologies, expansion of staff expertise, and student feedback. E-learning "champions" may be designated within the academic team and used to help encourage best practice throughout the department. In some cases, interventions can be formally assessed using an action research framework. Particular areas for focus should include learner engagement, actual learner resources, and the learner support framework. Once the infrastructure, course resources, and expertise have been established, additional markets can be explored with appropriate institutional backing.

\section{FUTURE DEVELOPMENTS IN E-LEARNING IN ARBORICULTURE}

The field of e-learning has undergone rapid and constant development over the last decade (Allen and Seaman 2010). As new 


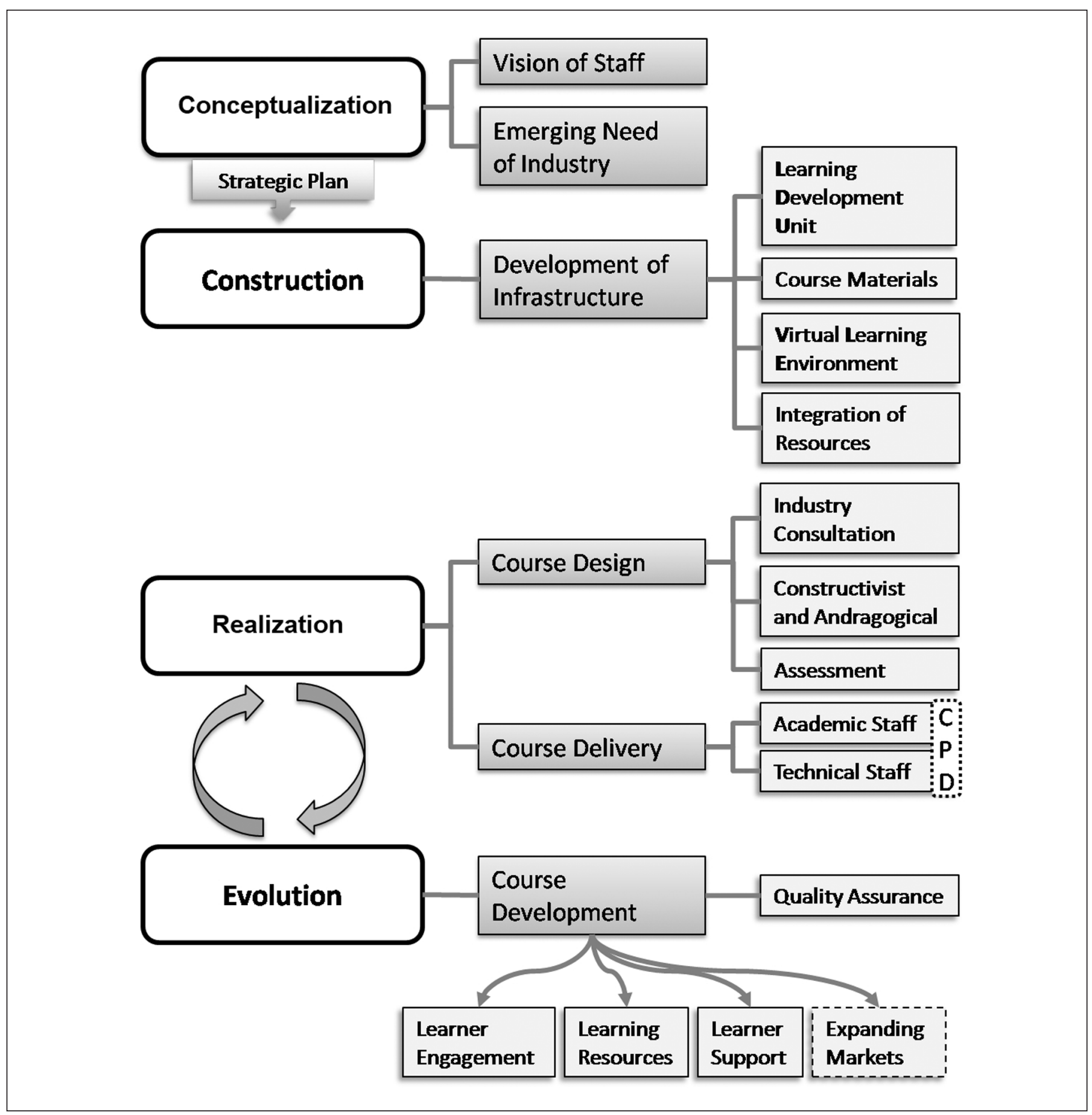

Figure 3. A model for online course development in arboriculture and other vocational subjects.

technologies emerge, these are being adapted and applied to elearning programs across the arboricultural industry in Britain and internationally. However, the FdSc and BSc (Hons) courses at Myerscough College are currently the only graduate level courses in arboriculture available online (ISA 2011). As such, the college has attracted students from many different countries, not only in Europe but also from the Americas, Africa, Asia, and Australasia (Slater 2011, pers. comm.). This demonstrates that where academic institutions and industry organizations are prepared to invest in human and material resources there are significant opportunities to meet the growing demand for online education programs in arboriculture. As courses attract a growing number of international students, course materials should reflect this diversity of backgrounds with a more internationalized content so that the local context of each learner is not forgotten (Poley 2010).

The college's experience in this field has shown that a huge amount of development and investment is required to manage online courses at the degree level. Rather than undertake the pro- 
cess themselves, other institutions may want to consider offering existing courses developed by other institutions with some of the course material adapted to meet their own requirements.

As arboriculture graduates have assumed an increasingly important role in the management of Britain's green infrastructure and urban landscapes, so the demand for postgraduate courses in arboriculture and urban forestry has gathered momentum within the wider greenspace industry. Many graduates of related professions, such as traditional forestry, landscape architecture and management, environmental studies, and urban planning, want to gain some specialist and advanced knowledge of urban tree management, which had not been part of their undergraduate education. To meet this demand, Myerscough College began offering its MSc in Arboriculture and Urban Forestry in 2008. This has been available by full-time and part-time study and has proved very successful, attracting not only British students but also many from overseas. However, the demand for this course to be available online has been growing and is presently under serious consideration by the College as another e-learning program.

There is no doubt that e-learning opportunities in arboriculture will expand even more. This expansion will not be limited to formal education courses at colleges or universities, but will embrace education and training at all levels in the industry (Vargas 2008). For example, online training and social networking opportunities are now available for members of local tree boards (Ries 2010) and the International Society of Arboriculture has recently launched an Online Learning Center to assist in the delivery of arboricultural education. Through these portals arborists and others will be able to access a wide range of training courses and materials that are available in various lengths on a variety of topics.

Acknowledgments. Dr. Dealga O'Callaghan who had the original idea to develop Myerscough's e-learning in arboriculture. Mick Cottam who put in much of the early work to get this started. Sandy Hunter and her team at the Learning Development Unit who have produced so many of the e-learning materials to such a high quality. Duncan Slater, Julie Smith and the other members of the Arboriculture Team at Myerscough College who produced e-learning materials and act as Course Tutors or Module Tutors.

\section{LITERATURE CITED}

Allen, I.E., and J. Seaman. 2010. Learning on Demand. Babson Survey Research Group.

Anderson, T., and F. Elloumi. 2004.Theory and Practice of Online Learning. Athabasca University. 421 pp.

Beetham, H., and R. Sharpe (Eds.). 2007. Rethinking Pedagogy for a Digital Age. Routledge. 288 pp.

Bridgeman, P.H. 1976. Tree Surgery: A Complete Guide. David and Charles. $144 \mathrm{pp}$.

Bridgeman, P.H. 2009. Merrist Wood 1967-1977. Essential Arb Issue 31, 24-26.

Cohen, L., and L. Manion. 1994. Research Methods in Education 4th Edition. Routledge: London, England. 440 pp.

Cole, R.A. 2000. Issues in Web-based pedagogy: A critical primer. Greenwood Press: Westport, Connecticut, U.S. 414 pp.

Dowson, D. 2010. Personal communication in the form of an e-mail to Mark Johnston from David Dowson, the Managing Director of Treelife, dated 06-04-2010.
Harasim, L., S.R. Hiltz, L. Teles, and M. Turoff. 1995. Learning Networks. MIT Press: Cambridge. 376 pp.

Harker, E.J., C.O. Ellis, A. Harraf, and M.D. Richards. 2005. Pioneering the Potential of IP Video: Integrating Macromedia Breeze Live and Breeze Presentation Software into a Learning Environment. Accessed 08/06/2007. <http://oregonstate.edu/instruct/ecampus/ucea/ presentations/Harker_Ellis_Harraf_Richards-UCEA_20050928Macromedia_Breeze.doc>

Hirons, A.D. 2007. Cool breeze or hot air: A critical analysis of the development of online arboriculture lecture resources using Macromedia Breeze. An Action Research Report. Myerscough College.

Honey, P., and A. Mumford. 1992. The Manual of Learning Styles. Peter Honey: London, England. 88 pp.

ISA. 2011. Academic Programs in Arboriculture Database. International Society of Arboriculture. Accessed 05/10/2011. <www.isa-arbor. $\mathrm{com} /$ students/careersInArboriculture/degreePrograms.aspx $>$

Jarvis, P. 2004. Adult Education and Lifelong Learning: Theory and Practice. 3rd edition. London: Routledge Falmer. Taylor \& Francis Group. 392 pp.

Johnston, M. 2001a. The Springtime of urban forestry in Britain developments between the 1st and 3rd Conferences 1988-1993, Part II. Arboricultural Journal 23:313-341.

Johnston, M. 2001b. British urban forestry in transition - developments between 1993-1998, Part II. Arboricultural Journal 25:153-178.

Khiewnavawongasa, S., R. Leong, and E. Schmidt. 2006. Learning a Web-Based Course Through Macromedia Breeze. 2006 ASEE Annual Conference \& Exposition: Excellence in Education. Chicago, Illinois, U.S. June 18-21, 2006.

Kim, K., and J. Bonk. 2006. The future of online teaching and learning in higher education. Educause Quarterly. 29:4

Knowles M., E.F. Holton III, and R.A. Swanson. 2005. The adult learner: The definitive classic in adult education and human resource development. 6th edition. Burlington, MA: Elsevier. 378 pp.

McPhenson, M., and M.B. Nunes. 2004. Developing innovation in Online Learning: An action research framework. Routledge: London, England. Taylor \& Francis Group. 160 pp.

Menhinick, O. 2010. Personal communication in the form of a letter to Mark Johnston from Oliver Menhinick, the Principal of The Horticultural Correspondence College, dated 04/27/2010.

Myerscough College 2005. Building on Success. Myerscough College Strategic Plan 2005 to 2010. Summary Version for Staff. Myerscough College.

Myerscough College 2006a. ILT Strategy August 2004, revised November 2006. Myerscough College.

Myerscough College 2006b. E-Learning Strategy 2006-2010. Learning development Unit, Myerscough College.

Piaget, J. 1970. Science of education and psychology of the child. Orion Press: New York, New York, U.S. 186 pp.

Poley, J. 2010. Globalization in Online Learning. In: K.E. Rudestam and J. Schoenholtz-Read (Eds.). 2010. Handbook of Online Learning 2nd Edition. Sage.

Ries, P. 2010. A New Online Learning and Social Networking Opportunity for Tree Boards. Partners in Community Forestry National Conference. November 9-11, 2010, Philadelphia, Pennsylvania. Accessed 03/10/2011. <www.arborday.org/shopping/conferences/brochures/ pcf/2010/graphics/post-conference/trees-development/paul-ries.pdf>

Rosenberg, M.J. 2001. E-Learning: Strategies for Delivering Knowledge in the Digital Age. McGraw Hill: New York, New York, U.S. 344 pp. 
Rudestam, K.E., and J. Schoenholtz-Read (Eds.). 2010. Handbook of Online Learning. Second edition. Sage Publications. 520 pp.

Sitzmann, T., K. Kraiger, D. Stewart, and R. Wisher. 2006. The comparative effectiveness of web-based and classroom instruction: A metaanalysis. Personnel Psychology 59:623-664.

Slater, D. 2008. Feel the noise: The perceptions of on-line students after the adding of audio files to a distance learning course. An Action Research Report. Myerscough College.

Slater, D. 2011. A personal communication in the form of an email dated 04-10-2011 to Andrew Hirons from Duncan Slater, Course Tutor for the FdSc Arboriculture (Online) at Myerscough College.

Vargas, L. 2008. Computer-based instruction: Breaking new ground in arboriculture. Arborist News 17:6.

Mark Johnston (corresponding author)

Myerscough College - Arboriculture

Myerscough College Bilsborrow, Preston PR3 ORY

United Kingdom

mjohnston@myerscough.ac.uk

Andrew Hirons

Myerscough College - Arboriculture

Preston

United Kingdom

Résumé. L'apprentissage en ligne se définit comme la fourniture d'informations à des fins d'enseignement, de formation ou d'éducation via des moyens électroniques. Au cours des deux dernières décennies, cela est devenu un moyen accru de délivrance de cours d'éducation de niveau supérieur étant donné que cette forme permet de fournir des bénéfices substantiels aux étudiants et aux institutions académiques. Le Collège Myerscough a été un pionnier dans le développement d'un diplôme complet en ligne sur l'arboriculture, non seulement en Grande-Bretagne où le collège est situé, mais aussi au niveau international avec des étudiants en ligne depuis de nombreux pays différents. Cet article décrit comment les programmes d'étude en ligne ont été développés, incluant les différents défis auxquels les programmes ont été confrontés ainsi que les interventions qui ont été faites pour les résoudre. On y présente aussi un modèle de développement de programmes à vocation d'enseignement en ligne en arboriculture et les industries connexes que les institutions pourraient souhaiter vouloir utiliser ou adapter. L'article conclut avec un aperçu des développements futurs anticipés avec la formation en ligne en arboriculture.

Zusammenfassung. E-learning ist eine Form von Fortbildung im Sinne von Lernen, Üben und Ausbildung durhc ein elektronisches Medium. In den letzten zwei Jahrzehnten wurde das ein zunehmend populärer Weg der Informationsweitergabe auch bei höheren Ausbildungskursen, weil diese Form der Informationsweitergabe signifikante Vorteile für die Studierenden und die akademischen Institute bietet. Das Myerscough College ist ein Pionier bei der Entwicklung eines völlig auf elektronischen Medien basierenden Abschlusskurses in Arboristik, und das nicht nur in Großbritannien, wo das College seinen Sitz hat, sondern auch international, wo nun Studenten aus vielen Ländern online hier studieren. Diese Studie beschreibt, wie E-learning-Programme entwickelt werden, einschließlich der unterschiedlichen Herausforderungen, denen sich das Programm gegenüber steht und die Interventionen zur Begegnung mit dieser Fragestellung. Die Studie präsentiert auch ein Modell zur Entwicklung von E-learning Programmen in Berufen der Arboristik und verwandten Berufszweigen, welche von anderen Instituten genutzt oder adaptiert werden wollen. Dieser Artikel schließt mit dem Hinweis auf mögliche, künftige Entwicklung im Bereich von E-learning in Arboristik.
Resumen. "E-learning" es la distribución de programas de aprendizaje, entrenamiento, o educación por medios electrónicos. En las pasadas dos décadas se ha dado un popular incremento en la liberación de cursos superiores de educación. Así, esta forma de educación proporciona beneficios significativos a los estudiantes y la institución académica. El Colegio Myerscough ha sido un pionero en el desarrollo de cursos completos de arboricultura "online" no solamente en Gran Bretaña, donde se encuentra el colegio, sino también internacionalmente con estudiantes que realizan ahora diferentes cursos "online" en muchos países diferentes. Este reporte describe cómo fueron desarrollados los programas de grado, incluyendo los variados desafíos y las intervenciones que fueron hechas para superarlos. También presenta un modelo para el desarrollo de programas vocacionales "E-learning" para arboricultura e industrias relacionadas, que otras instituciones pueden desearlos para usar o adaptar. El reporte concluye con una indicación de futuros desarrollos "Elearning" en arboricultura. 